\title{
Comparison of Automated Broth Microdilution System (Vitek-2) and Agar Dilution Method in the Detection of Fosfomycin Susceptibility in $E$. coli and $K$. pneumoniae Isolates Causing Urinary Tract Infection
}

Üriner Sistem Enfeksiyonu Etkeni E. coli ve K. pneumoniae Izolatlarında Fosfomisin DuyarlıIı̆ının Saptanmasında Otomatize Sıvı Mikrodilüsyon Sistemi (Vitek-2) ile Agar Dilüsyon Yönteminin Karşılaştırılması

\author{
(1) Ezgi AKPINAR ${ }^{1}$, ๑ Nilgün KANSAK ${ }^{1}$, ๑ Sebahat AKSARAY ${ }^{2}$ \\ 1 University of Health Sciences Turkey, Haydarpaşa Numune Training and Research Hospital, Clinic of Medical Microbiology, Istanbul, Turkey \\ 2 University of Health Sciences Turkey, Hamidiye Faculty of Medicine, Department of Medical Microbiology, Istanbul, Turkey
}

\section{Abstract}

Introduction: Agar dilution is the reference method recommended by the European Committee on Antimicrobial Susceptibility Testing (EUCAST) for the detection of fosfomycin susceptibility in Gram-negative bacteria. However, this method is difficult to apply routinely in microbiology laboratories. For this reason, commercial automated systems have been developed to detect antibiotic susceptibility more easily and practically. In our study, we aimed to evaluate the utility of commercial automated broth microdilution system in routine studies to detect fosfomycin susceptibility by comparing it with the gold standard agar dilution method.

Materials and Methods: A total of 100 isolates of E. coli and K. pneumoniae isolated as urinary tract infection agents from urine samples, which were sent to Haydarpaşa Numune Training and Research Hospital, Medical Microbiology Laboratory between 01.06.2019 and 31.12.2019 were included in our study. Isolates were identified with matrix assisted lazer desorption/ionization-time of flight mass spectrometry (MALDI-TOF MS) (BioMerieux, France), and antibiotic susceptibility tests were performed with an automated broth microdilution system (Vitek-2, BioMerieux, France). Fosfomycin susceptibility was studied with the reference agar dilution method and the results were evaluated according to the EUCAST V.10.0 recommendations. In the evaluation made to compare the two methods, categorical agreement (CA), essential agreement (EA), very major error (VME), and major error (ME) values were calculated and the results were evaluated according to ISO 20776-1 criteria (CA and EA $\geq 90 \%$; ME and VME <3\%).

Results: When the data of the two methods were compared, CA and EA were found 100\% for E. coli strains and 95.5\% and 94.4\% for K. pneumoniae strains, respectively. No ME or VME was detected for E. coli strains. While no VME was detected in K. pneumoniae strains, ME rate was $18 \%$.

Conclusion: Based on the high CA rates in our study, it was thought that the Vitek-2 system would be suitable for routine laboratory use. However, due to the high ME rates in $K$. pneumoniae strains, it was concluded that the results should not be reported unless confirmed with the reference method, especially in resistant isolates.

Keywords: Fosfomycin, agar dilution, automated broth microdilution method, Vitek-2, Gram-negative bacteria

$\ddot{0} z$

Giriş: Gram-olumsuz bakterilerde fosfomisin duyarlıığının saptanması için Avrupa Antimikrobiyal Duyarlılık Testleri Komitesi (EUCAST) tarafından önerilen referans yöntem agar dilüsyondur. Ancak bu yöntemin mikrobiyoloji laboratuvarlarında rutin olarak uygulanması zordur. Bu nedenle daha kolay ve pratik bir şekilde antibiyotik duyarlıı̆̆ını saptayacak ticari otomatize sistemler geliştirilmiştir. Çalışmamızda altın standart agar dilüsyon

Cite this article as: Akpınar E, Kansak N, Aksaray S. Comparison of Automated Broth Microdilution System (Vitek-2) and Agar Dilution Method in the Detection of Fosfomycin Susceptibility in E. coli and K. pneumoniae Isolates Causing Urinary Tract Infection. Mediterr J Infect Microb Antimicrob. 2021;10:26. 
yöntemi ile karşılaştırarak, fosfomisin duyarııı̆ıını saptamada ticari otomatize sıvı mikrodilüsyon sisteminin rutin çalışmalarda kullanılabilirliğinin değerlendirilmesi amaçlanmıştır.

Gereç ve Yöntem: Haydarpaşa Numune Eğitim ve Araştırma Hastanesi, Tıbbi Mikrobiyoloji Laboratuvarı'na 01.06.2019-31.12.2019 tarihleri arasında çeşitli kliniklerden gönderilen idrar örneklerinden üriner sistem enfeksiyon etkeni olarak izole edilen toplam 100 adet $E$. coli ve K. pneumoniae suşu dahil edilmiştir. İzolatların tanımlaması matrix assisted lazer desorption/ionization-time of flight mass spectrometry (MALDI-TOF MS) (BioMerieux, Fransa) ile, antibiyotik duyarlılık testleri otomatize sıvı mikrodilüsyon sistemi (Vitek-2, BioMerieux, Fransa) ile yapılmıştır. Fosfomisin duyarlılı̆̆ı referans agar dilüsyon yöntemi ile çalışılarak sonuçlar EUCAST V.10.0 önerilerine göre değerlendirilmiştir. İki yöntemin karşılaştırılması amacıyla yapılan değerlendirmede kategorik uyum (KU), temel uyum (TU), çok büyük hata (ÇBH), büyük hata (BH) oranları hesaplanarak sonuçlar ISO 20776-1 kriterlerine (TU ve $\mathrm{KU} \geq \% 90$; $\mathrm{BH}$ ve ÇBH <\%3) göre yorumlanmıştır.

Bulgular: İki yöntemin verileri karşılaştırıldığında KU ve TU sırasıyla E. coli suşları için \%100, K. pneumoniae suşları için \%95,5 ve \%94,4 olarak saptanmıştır. E. coli suşları için BH ve ÇBH saptanmamıştır. K. pneumoniae suşlarında ise ÇBH saptanmazken, \%18 oranında BH saptanmıştır.

Sonuç: Çalışmamızda KU oranlarının yüksek olmasına dayanarak Vitek-2 sisteminin rutin laboratuvarda kullanımının uygun olacağı düşünülmüştür. Ancak özellikle K. pneumoniae suşlarındaki BH oranının yüksek olması nedeniyle, özellikle dirençli izolatlarda referans yöntemle konfirme edilmeden sonuçların raporlanmaması gerektiği kanaati oluşmuştur.

Anahtar Kelimeler: Fosfomisin, agar dilüsyon, otomatize sıvı mikrodilüsyon yöntemi, Vitek-2, Gram-olumsuz bakteri

\section{Introduction}

Urinary tract infections (UTI) are one of the most common infections that constitute an important part of hospitalizations and related health expenses ${ }^{[1]}$. Gram-negative bacteria are the most common cause of UTI. Escherichia coli (E. coli) is responsible for more than $90 \%$ of community-acquired UTI. The second most common agent is Klebsiella pneumoniae ( $K$. pneumoniae) $)^{[2]}$.

According to the Infectious Diseases Society of America (IDSA) guidelines, fosfomycin is one of the first antibiotics recommended in the treatment of $\mathrm{UTI}^{[3]}$. Rapid absorption after oral administration, urinary excretion concentration, biofilm activity and efficacy against many drug-resistant microorganisms such as extended spectrum beta-lactamase (ESBL) and AmpC-producing Enterobacteriaceae make it advantageous to use fosfomycin in the treatment of UTI ${ }^{[1]}$.

Fosfomycin binds to MurA, the main enzyme of peptidoglycan biosynthesis, and blocks peptidoglycan synthesis at the first stage and causes cell death ${ }^{[4]}$. Resistance to fosfomycin can develop through three different mechanisms including transport impairment, target exchange and enzymatic inactivation. Resistance to fosfomycin may develop in $E$. coli as a result of mutation caused by changes in carrier GIpTand UhpTchromosomal genes and active center of murA. Inactivation of fosfomycin by metallo enzymes ( $f \circ s A$, fos $B$, fos $X$ ) is of epidemiological importance. fos $A$ and its homologous genes have been identified in ESBL positive E. coli, carbapenemase positive $K$. pneumoniae plasmids and chromosomes in Klebsiella spp ${ }^{[5]}$.

Agar dilution, broth microdilution, disk diffusion and Etest techniques can be used to determine the in vitro susceptibility of Gram-positive and Gram-negative pathogens to fosfomycin. The reference method recommended by the European Committee on Antimicrobial Susceptibility Testing (EUCAST) and the Clinical and Laboratory Standards Institute (CLSI) for the detection of fosfomycin susceptibility in Gram-negative bacteria is agar dilution ${ }^{[6,7]}$. Since the criteria for evaluating and interpreting disk diffusion and minimum inhibitory concentration (MIC) results are different in CLSI and EUCAST guidelines, susceptibility interpretation varies according to the selected guideline recommendations. Both guidelines recommend adding glucose-6-phosphate (G6P) in susceptibility testing. Thus, in in vitro conditions, the entry of fosfomycin into the bacterial cell increases and a result close to the theoretical value is obtained. However, it is difficult to apply the agar dilution method routinely in microbiology laboratories.

Fosfomycin susceptibility is determined more easily and practically in automated systems. In our study, it was aimed to compare the automated broth microdilution system with the gold standard agar dilution method in detecting the susceptibility of fosfomycin, to evaluate its performance and to examine its usability in routine studies.

\section{Materials and Methods}

Bacteria Strains

The study included 100 randomly selected $E$. coli and $K$. pneumoniae strains which were isolated from urine culture specimens, identified with matrix assisted lazer desorption/ ionization-time of flight mass spectrometry (MALDI-TOF MS) (BioMerieux, France) and tested for antibiotic susceptibility using an automated broth microdilution system (Vitek-2, BioMerieux, France). Bacterial colonies were taken from the fresh culture, which was previously stocked and revived by planting on agar with 5\% sheep blood, and a suspension equal to 0.5 McFarland turbidity $\left(1.5-2 \times 10^{8}\right.$ colony forming units; CFU/ $\mathrm{ml)}$ was prepared in sterile saline by direct colony suspension method. The McFarland setting was made automatically using the optical reader (densiCHEK, BioMerieux, France).

\section{Preparation of Antibiotic Stock and Study Solutions}

Pure fosfomycin disodium hydrate (Sigma-Aldrich, USA) in powder form and sterile distilled water as antibiotic diluent 
were used for agar dilution test. Fosfomycin stock solution (containing $10240 \mathrm{mg} / \mathrm{l}$ fosfomycin) was prepared by dissolving $409.6 \mathrm{mg}$ of fosfomycin, which was weighed under sterile conditions according to the volume/weight/potency formula and considered to have a potency of 1 , in sterile $40 \mathrm{ml}$ of distilled water. Study solutions were prepared from the stock solution by making serial dilutions.

\section{Preparation of Agar Plates}

Mueller-Hinton Agar (Condalab, Spain) was prepared in accordance with the company recommendations and G6P (25 $\mathrm{mg} / \mathrm{l})$ (Sigma-Aldrich, USA) was added before pouring. The antibiotic study solutions obtained by serial dilution were mixed with Mueller-Hinton agar in volumetric flasks considering $1 / 10$ antibiotic/agar dilution ratio and then poured into petri dishes with an average thickness of $4 \mathrm{~mm}(20 \mathrm{ml})$. Thus, the appropriate final antibiotic concentration $(0.25 \mathrm{mg} / \mathrm{l}-1024$ $\mathrm{mg} / \mathrm{ll}$ ) was obtained in petri dishes.

\section{Agar Dilution Method}

Agar dilution was made according to the guidelines recommendations of the EUCAST descriptive document 3.1 $1^{[8]}$. For this, first of all, a bacteria density of $10^{7} \mathrm{CFU} / \mathrm{ml}$ was obtained by diluting 0.5 MacFarland bacterial suspension at a ratio of 1:10. Later, by taking $1 \mu$ l of bacteria solution from the tube with the help of an automatic pipette, the final bacteria concentration on the agar plate was achieved to be $10^{4} \mathrm{CFU} / \mathrm{ml}$ when planting was performed. Bacteria cultivation was carried out starting from the plate containing low antibiotic concentration towards the petri dishes containing higher antibiotic concentration. After the inoculum areas dried at room temperature, the petri dishes were left to incubate for $18 \pm 2$ hours in an inverted oven at $35 \pm 2{ }^{\circ} \mathrm{C}$.

\section{Studying Quality Control Strains}

Growth control of the medium and isolates was carried out by bacterial cultivation on antibiotic-free agar plates. Quality control of the agar dilution test was performed using Escherichia coli ATCC 25922, Staphylococcus aureus ATCC 29213, Pseudomonas aeruginosa 27853, and Enterococcus faecalis ATCC 29212 strains.

\section{Evaluation of MIC Results}

After the incubation, the results were evaluated independently from each other by double-eye control. The lowest antibiotic concentration in which growth was inhibited was determined as MIC (Figure 1). Minimum inhibitory concentration results were evaluated according to EUCAST v. 10.0 recommendations, and MIC values $\leq 32 \mathrm{mg} / \mathrm{l}$ were interpreted as susceptible, MIC values $>32 \mathrm{mg} / \mathrm{l}$ as resistant ${ }^{[6]}$.

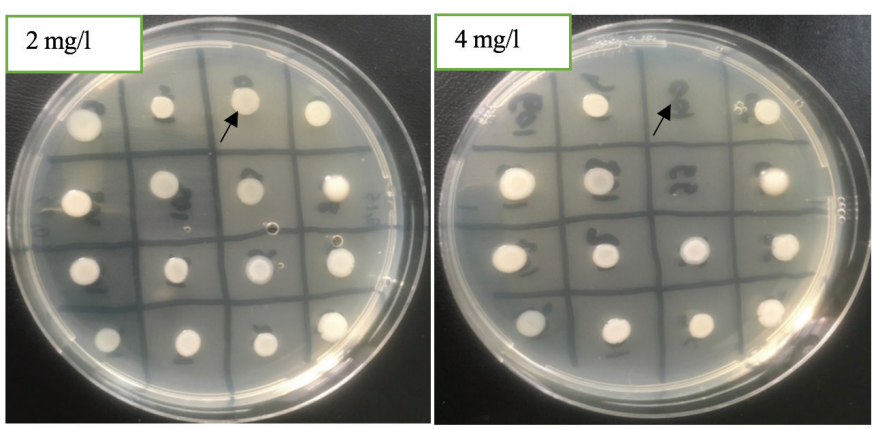

Figure 1. Evaluation of fosfomycin MIC results on agar plates (example: Isolate number $100 \mathrm{MIC}: 4 \mathrm{mg} / \mathrm{l}$ )

MIC: Minimum inhibitory concentration

\section{Evaluation of Test Performance}

The consistency and error rates of Vitek-2 results compared with the reference method, essential agreement (EA) (results with MIC value within \pm 1 dilution), categorical agreement (CA) (number of overlapping $[\mathrm{S}, \mathrm{R}]$ categorical results), major error (ME) (sensitive due to reference method, results with false resistance) and very major error (VME) (resistant due reference method, results with false sensitivity) rates were calculated. Agreement and error rates were evaluated according to ISO 20776-1 criteria. (EA and CA $\geq 90 \%$; $\mathrm{ME}$ and $\mathrm{VME}<3 \%$ ) $^{[9]}$.

\section{Results}

With the agar dilution method, $85.7 \%$ of 56 E. coli strains and $25 \%$ of $44 K$. pneumoniae strains were found to be susceptible to fosfomycin. $\mathrm{MIC}_{50}$ and $\mathrm{MIC}_{90}$ values for $E$. coli were found as $2 \mathrm{mg} / \mathrm{l}$ and $128 \mathrm{mg} / \mathrm{l}$, and $\mathrm{MIC}_{50}$ and $\mathrm{MIC}_{90}$ values for $K$. pneumoniae were found as $64 \mathrm{mg} / \mathrm{l}$ and $1024 \mathrm{mg} / \mathrm{l}$, respectively (Figure 2).

With the Vitek-2 automated broth microdilution system, 85.7\% of $56 \mathrm{E}$. colistrains and $20.5 \%$ of $44 \mathrm{~K}$. pneumoniae strains were

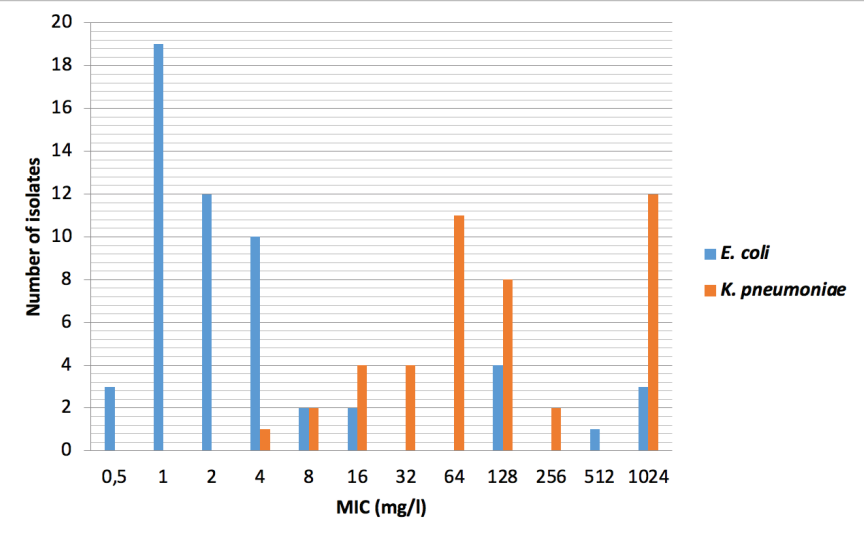

Figure 2. Distribution of fosfomycin MIC values of $E$. coli and $K$. pneumoniae strains determined with agar dilution method

MIC: Minimum inhibitory concentration 
found susceptible to fosfomycin. The results are summarized in Table 1.

The CA rates of Vitek-2 results with the reference method were found to be $100 \%$ for $E$. coli strains, $95.5 \%$ for $K$. pneumoniae strains, and $98 \%$ for a total of 100 strains. In the automated microdilution system, fosfomycin MIC values smaller than 16 and greater than 256 are not given exactly, they are given as $\leq 16$ and $\geq 256$. For this reason, strains with MIC values of 16 and 256 in the automated microdilution system were not taken into consideration while calculating the EA. EA was found to be $100 \%$ for E. coli, $94.4 \%$ for K. pneumoniae, and $95.5 \%$ in total. Results are shown in Table 2.

In E. coli strains, ME was not detected, and ME was detected in 2 K. pneumoniae strains (18\%). The ME rate was calculated as $3.4 \%$ for all strains included in the study. In our study, no strains with VME were found for both types of bacteria. ME and VME rates are shown in Table 3.

\section{Discussion}

The increase in antibiotic-resistant pathogenic bacteria is a primary public health problem, and the problem of resistance needs to be solved urgently. Since the development of new antibiotics is a costly and time consuming process, the rational use and recovery of old antibiotics such as polymyxins, fusidic acid and fosfomycin has come to the fore. Therefore, it is important to accurately determine the fosfomycin susceptibility of the E. coli and $K$. pneumoniae strains isolated as causative agents in UTIs.

EUCAST and CLSI recommend agar dilution as a reference method for determining fosfomycin susceptibility. However, the agar dilution method is labor intensive in the daily routine of microbiology laboratories and it is a time consuming method. Disk diffusion or gradient strip tests used in routine studies for other antibiotics cause uncertainty in terms of interpretation of the results due to the formation of isolated colonies within the inhibition zones for fosfomycin.

Since the reference agar dilution test is difficult to apply in routine studies, easier and faster methods are needed. Automated systems are frequently used methods because they reduce the workload in laboratories, have high repeatability, and can manage data with expert system analysis. Vitek-2 system is routinely used in our laboratory to detect antibiotic susceptibility results. In our study where we compared the MIC values obtained by automated broth microdilution method (Vitek-2) with the agar dilution method in order to determine the susceptibility of $E$. coli and K. pneumoniae strains to fosfomycin, we found that CA was $98 \%$. This rate was $100 \%$ for $E$. coli isolates and $95.5 \%$ for K. pneumoniae isolates. Disagreement was detected in two of the $K$. pneumoniae isolates with the agar dilution method, and they were in the form of ME. When the literature was searched, a limited number of studies were found in Turkey investigating fosfomycin resistance in uropathogenic $K$. pneumoniae and E. coli isolates using the gold standard method (agar dilution method), and no study comparing the reference method with Vitek-2 was found. Demirci-Duarte et al. ${ }^{[10]}$ found fosfomycin resistance at a rate of $2.7 \%$ with the agar dilution method in their study conducted with 299 uropathogenic $E$. coli isolates. In a thesis study conducted by Nigiz ${ }^{[11]}$ in 2020 including $235 E$. coli and $56 \mathrm{~K}$. pneumoniae isolates, fosfomycin resistance was investigated only with the agar dilution method, which was the gold standard method, and fosfomycin resistance was found to

Table 1. Agar dilution and Vitek-2 MIC results of the isolates

\begin{tabular}{|c|c|c|c|c|c|c|c|c|c|c|c|c|c|c|c|c|c|}
\hline & \multicolumn{12}{|c|}{ Agar dilution MIC results } & \multicolumn{5}{|c|}{ Vitek-2 MIC results } \\
\hline $\mathrm{mg} / \mathrm{L}$ & 0.5 & 1 & 2 & 4 & 8 & 16 & 32 & 64 & 128 & 256 & 512 & 1024 & $\leq 16$ & 32 & 64 & 128 & $\geq 256$ \\
\hline E. coli & 3 & 19 & 12 & 10 & 2 & 2 & - & - & 4 & - & 1 & 3 & 48 & - & 2 & 2 & 4 \\
\hline
\end{tabular}

MIC: Minimum inhibitory concentration

Table 2. Categorical and essential agreement rates of Vitek-2 automated broth microdilution method

\begin{tabular}{l|l|l|l|l|l|l}
\hline & \multicolumn{4}{l|}{ Categorical agreement $(\mathbf{n}=\%)$} & \multicolumn{3}{l}{ Essential agreement $(\mathbf{n}=\%)$} \\
\hline Method & E. coli & K. pneumoniae & Total & E. coli & K. pneumoniae & Total \\
\hline $\begin{array}{l}\text { Automated broth } \\
\text { microdilution (Vitek-2) }\end{array}$ & $56 / 56(100 \%)$ & $42 / 44(95.5 \%)$ & $98 / 100(98 \%)$ & $4 / 4(100 \%)$ & $17 / 18(94.4 \%)$ & $21 / 22(95.5 \%)$
\end{tabular}

Table 3. Major error and very major error rates detected by Vitek-2 automated broth microdilution method

\begin{tabular}{l|l|l|l|l|l|l}
\hline \multirow{2}{*}{ Method } & \multicolumn{4}{|l|}{ Major error $(\mathbf{n}=\%)$} & \multicolumn{3}{l}{ Very major error $(\mathbf{n}=\%)$} \\
\cline { 2 - 6 } & E. coli & K. pneumoniae & Total & E. coli & K. pneumoniae & Total \\
\hline $\begin{array}{l}\text { Automated broth } \\
\text { microdilution (Vitek-2) }\end{array}$ & $0 / 48(0 \%)$ & $2 / 11(18 \%)$ & $2 / 59(3.4 \%)$ & $0 / 8(0 \%)$ & $0 / 33(0 \%)$ & $0 / 41(0 \%)$
\end{tabular}


be $3 \%$ in $E$. coli isolates and $16.1 \%$ in $K$. pneumoniae isolates. It is seen that the rates of resistance reported in both studies are lower than in our study.

Very different rates have been reported regarding the performance of automated systems in detecting fosfomycin susceptibility. Van den Bijllaardt et al. ${ }^{[12]}$ studied the fosfomycin susceptibility of 775 E. coli and 201 K. pneumoniae strains from different centers and various samples (urine, blood, etc.) between 2016-2017 with Etest, MIC Test Strip (MTS) test, Vitek-2, Phoenix and disk diffusion, and compared the results with the agar dilution method. The researchers found the susceptibility rate of fosfomycin to be $95.9 \%$ for E. coli strains and $87.6 \%$ for $K$. pneumoniae strains. Unlike our strains, isolates in that study appeared to be composed of more susceptible strains. In that study, CA rates of Vitek-2 and agar dilution method were 99\% for E. coli, 94.5\% for K. pneumoniae, and CA was found to be acceptable. The ME in that study was found to be $0.3 \%$ for E. coli and $4 \%$ for $K$. pneumoniae. The VME in that study was found to be $18.8 \%$ for E. coli, and $16 \%$ for K. pneumoniae. The high rate of VME in that study was thought to be due to the low number of resistant strains ( $4.1 \%$ in $E$. coli isolates; $12.4 \%$ in $K$. pneumoniae). The researchers concluded that due to the high error rates detected in both $E$. coli (23.3\% Etest, 18.5\%/MTS, 18.8\%/Vitek-2, 12.5\%/Phoenix and 12.9\%/Disk diffusion) and K. pneumoniae (22.7\%/Etest and MTS), 16\%/Vitek-2 and 12\%/ Phoenix) isolates, no method could be a suitable alternative to agar dilution test.

In the study of Camarlinghi et al. ${ }^{[13]}$ published in 2018, the fosfomycin susceptibility of $78 \mathrm{~K}$. pneumoniae carbapenemase (KPC) forming K. pneumoniae strains were studied with Sensitre, Etest, disk diffusion, MTS and Vitek-2 and compared with the reference method. The susceptibility of the strains to fosfomycin was $57.7 \%$, and the rate of susceptible strains was higher than our data (25\%). In that study, when the automatized system Vitek-2 and agar dilution method were compared, CA was found to be 52.6\%, EA 71.8\%, ME 75.6\%, and VME 9.1\%. When compared to our study; it appeared that the CA and EA ratios were lower than our results and did not meet the ISO criteria. When our error rates were compared, it was noteworthy that both the ME and the VME rates were significantly higher than our data. Based on the data they obtained, the researchers concluded that the susceptibility results obtained by these methods were unacceptable since none of the methods met the ISO criteria.

Karlowsky et al. ${ }^{[14]}$ examined a total of 554 E. colistrains, 162 of which were isolated from urine samples, in terms of fosfomycin susceptibility with agar dilution, disk diffusion and Etest methods in their study published in 2020. Fosfomycin MIC50 value was determined as $\leq 1 \mathrm{mg} / \mathrm{l}$, MIC90 value was determined as $4 \mathrm{mg} / \mathrm{l}$. Fosfomycin susceptibility rate was $98.4 \%$. In that study; a total of 61 isolates (12 strains with agar dilution MIC value 32 and 49 strains with low MIC values) were studied with the Vitek-2 automated broth microdilution method and compared with the reference method. The MIC values of Vitek-2 were one to three dilutions lower in all 8 isolates with agar dilution MIC values of $64-256 \mathrm{mg} / \mathrm{l}$. Low MIC values detected by Vitek-2 resulted in minor error in 5 of 6 isolates with MIC $\geq 128 \mathrm{mg} / \mathrm{l}$, and in 5 of 9 isolates with $\mathrm{MIC}>32 \mathrm{mg} / \mathrm{l}$ resulted in VME. As another remarkable finding in that present study, when the susceptibility results were evaluated according to CLSI, no ME and VME were detected, but when the results were evaluated according to EUCAST, VME was detected in $44.4 \%$ in disk diffusion test, and in 33.3\% in Etest.

In the study by Aprile et al. ${ }^{[15]}$ including 85 carbapenem resistant K. pneumoniae and $35 \mathrm{ESBL}$ positive E. coli strains, the susceptibility of the strains was studied with broth microdilution, gradient test, Vitek-2 automated system, Phoenix automated system and agar dilution method. The CA and error rates of the results were calculated according to the reference method agar dilution. Fosfomycin resistance rate was higher in K. pneumoniae strains than E. coli strains. The CA ratios of the Vitek-2 automated system were $80 \%$ in ESBL positive $E$. coli isolates, $84 \%$ in KPC positive $K$. pneumoniae isolates, 93\% in NDM OXA-48 positive $K$. pneumoniae isolates, and 100\% in OXA-48 positive $K$. pneumuniae isolates. In that study, unlike our study, CA was found below the acceptable value $(<90 \%)$ for E. coli and KPC positive K. pneumoniae strains. For the Vitek-2 system, VME was not found in E. coli and OXA-48 positive $K$. pneumoniae strains. Very major error was calculated as 2\% in KPC positive K. pneumoniae strains and 7\% in NDM OXA-48 positive $K$. pneumoniae strains. The rate of ME was $20 \%$ in E. coli strains and 14\% in KPC positive K. pneumoniae strains, and no ME was detected in NDM and OXA-48 positive K. pneumoniae strains. Similar to our study, the ME ratio was found above the acceptable value in KPC positive strains. Therefore, the researchers commented that the agar dilution method was the only reference method for fosfomycin resistant KPC positive $K$. pneumoniae strains. In addition, they concluded that if the ESBL positive $E$. coli isolates were susceptible to the automated system, those results did not need to be verified with the reference method, and that for resistant isolates, the reference method could be verified with gradient test because the reference method was difficult to apply routinely. In that study, Phoenix system, which was one of the commercial broth microdilution systems, was found to be categorically compatible $(>90 \%)$ for all isolates and its performance was determined better than the Vitek-2 system.

The limitation of our study was that it did not to examine whether there was a change in the resistance profile of $E$. coli and $K$. pneumoniae isolates, such as ESBL or carbapenemase, 
according to their resistance profiles. Another limitation was that the comparison was made in a small number of isolates, since strains with MIC values of $\leq 16 \mathrm{mg} / \mathrm{l}$ or $\geq 256 \mathrm{mg} / \mathrm{l}$ in the automated system could not be taken into consideration while calculating SC.

\section{Conclusion}

As a result, Vitek-2 automated broth microdilution method was found to be highly consistent (90\%) in terms of CA with the reference method in determining the susceptibility of fosfomycin. While no error was detected in E. coli strains, our ME rate in $K$. pneumoniae strains was above the acceptable value. Based on the high rates of $C A$, it was thought that the Vitek-2 system would be suitable for routine laboratory use. However, due to the high error rates in K. pneumoniae strains, it was concluded that the results should not be reported without confirming with the reference method, especially in isolates with resistant results.

\section{Ethics}

Ethics Committee Approval: This study was conducted with the approval of the Haydarpaşa Numune Training and Research Hospital, Clinical Research Ethics Committee (decision number: KAEK 2019/KK/173, date: 16.12.2019).

Informed Consent: Our study was carried out with isolates in which fosfomycin susceptible/resistant E. coli and Klebsiella pneumoniae were detected among the samples whose urinary culture was requested by the clinician considering the possibility of urinary infection, and patient consent was not obtained.

Peer-review: Externally peer-reviewed.

\section{Authorship Contributions}

Surgical and Medical Practices: E.A., N.K., Concept: E.A., N.K., S.A., Design: E.A., N.K., S.A., Data Collection or Processing: E.A., N.K., Analysis or Interpretation: E.A., N.K., S.A., Literature Search: E.A., N.K., S.A., Writing: E.A., N.K., S.A.

Conflict of Interest: No conflict of interest was declared by the authors.

Financial Disclosure: The authors declared that this study received no financial support.

\section{References}

1. Matthews PC, Barrett LK, Warren S, Stoesser N, Snelling M, Scarborough $M$, Jones $N$. Oral fosfomycin for treatment of urinary tract infection: a retrospective cohort study. BMC Infect Dis. 2016;16:556.

2. Uzun $A$, Gülen $D$, Tanriverdi $Y$, Demet Kaya $A$, Fosfomisin ve bazı antimikrobiyal ajanların üriner Escherichia coli izolatlarına in vitro etkinliğinin değerlendirilmesi. Klimik Derg. 2012;25:77-80.

3. Gupta $K$, Hooton TM, Naber KG, Wullt B, Colgan R, Miller LG, Moran GJ, Nicolle LE, Raz R, Schaeffer AJ, Soper DE, Infectious Diseases Society of America; European Society for Microbiology and Infectious Diseases. International clinical practice guidelines for the treatment of acute uncomplicated cystitis and pyelonephritis in women: a 2010 update by the Infectious Diseases Society of America and the European Society for microbiology and Infectious diseases. Clin Infect Dis. 2011;52:e103-20.

4. Castañeda-García A, Blázquez J, Rodríguez-Rojas A. Molecular mechanisms and clinical impact of acquired and intrinsic fosfomycin resistance. Antibiotics (Basel). 2013;2:217-36.

5. Díez-Aguilar M, Cantón R. New microbiological aspects of fosfomycin. Rev Esp Quimioter. 2019;32:8-18.

6. The European Committee on Antimicrobial Susceptibility Testing - EUCAST MIC and zone diameter distributions and ECOFFs V.10.0 2020. Available from: http://www.eucast.org

7. Clinical and Laboratory Standards Institute (CLSI). Performance standards for antimicrobial susceptibility testing; $30^{\text {th }}$ informational supplement. CLSI document M100-S76. Wayne, PA: CLSI: 2020. Available from: https://clsi. org/media/3481/m100ed30_sample.pdf

8. European Committee for Antimicrobial Susceptibility Testing (EUCAST) of the European Society of Clinical Microbiology and Infectious Diseases (ESCMID). EUCAST Definitive Document E.DEF 3.1, June 2000: Determination of minimum inhibitory concentrations (MICs) of antibacterial agents by agar dilution. Clin Microbiol Infect. 2000;6:509-15.

9. ISO 20776-1:2019 Susceptibility testing of infectious agents and evaluation of performance of antimicrobial susceptibility test devices - Part 1: Brothmicro-dilution reference method for testing the in vitro activity of antimicrobial agents against rapidly growing aerobic bacteria involved in infectious diseases. Available from: www.iso.org/standard

10. Demirci-Duarte $S$, Unalan-Altintop T, Eser OK, Cakar A, Altun B, Sancak B, Gur D. Prevalence of 025b-ST131 clone and fosfomycin resistance in urinary Escherichia coli isolates and their relation to CTX-M determinant. Diagn Microbiol Infect Dis. 2020;98:115098.

11. Nigiz Ş. Yatan hastaların idrar kültürlerinden izole edilen Klebsiella spp., Escherichia coli, Acinetobacter baumannii, Pseudomonas aeruginosa izolatlarının antibiyotik duyarlııklarının in vitro yöntemlerle saptanması ve fosfomisine direnç mekanizmalarının araştırılması. Yüksek lisans tezi. Ankara: T.C. Hacettepe Üniversitesi Sağlık Bilimleri Enstitüsü;2020.

12. Van den Bijllaardt W, Schijffelen MJ, Bosboom RW, Cohen Stuart J, Diederen B, Kampinga G, Le TN, Overdevest I, Stals F, Voorn P, Waar K, Mouton JW, Muller AE, Susceptibility of ESBL Escherichia coli and Klebsiella pneumoniae to fosfomycin in the Netherlands and comparison of several testing methods including Etest, MIC test strip, Vitek2, Phoenix and disc diffusion. J Antimicrob Chemother. 2018;73:2380-7.

13. Camarlinghi G, Parisio EM, Antonelli A, Nardone M, Coppi M, Giani T, Mattei $\mathrm{R}$, Rossolini GM, Discrepancies in fosfomycin susceptibility testing of KPCproducing Klebsiella pneumoniae with various commercial methods. Diagn Microbiol Infect Dis. 2019;93:74-6.

14. Karlowsky JA, Lagacé-Wiens PRS, Laing NM, Baxter MR, Adam HJ, Zhanel GG. Susceptibility of clinical isolates of Escherichia coli to fosfomycin as measured by four in vitro testing methods. J Clin Microbiol. 2020;58:e0130620.

15. Aprile A, Scalia G, Stefani S, Mezzatesta ML. In vitro fosfomycin study on concordance of susceptibility testing methods against ESBL and carbapenem-resistant Enterobacteriaceae. J Global Antimicrob Resist. 2020;23:286-9. 